Nama : Widyastuti Pratiwi

NIM : 90100118079

\title{
Sejarah Perkembangan Ekonomi Islam
}

Sebagai bagian integral dari ajaran Islam, pembahasan mengenai ilmu ekonomi sesungguhnya telah berlangsung sejak diturunkannya Al-Quran kepada umat manusia. Meski demikian, para ulama tidak pernah mengklaim ekonomi sebagai sebuah disiplin ilmu tersendiri. Klaim "economics as a science" sendiri baru muncul pada abad 19 oleh Alfred Marshall, sehingga ada kesan seolah-olah ilmu ekonomi itu lahir dan berkembang di Barat, dengan menafikan peran dunia Islam yang sesungguhnya sangat signifikan. Apalagi hal tersebut diperparah dengan tesis Great Gap Analysis-nya Joseph Schumpeter, yang menyatakan bahwa dunia ini berada dalam masa kegelapan selama kurang lebih 5 abad. Secara umum, periodisasi ilmu ekonomi Islam ini dapat dibagi menjadi tiga tahap besar. Pertama, periode klasik ekonomi Islam, yang dimulai sejak misi kenabian Muhammad SAW hingga tahun $1500 \mathrm{M}$, tepatnya pada masa kejatuhan Andalusia. Kedua, periode stagnasi dan transisi, dimulai tahun $1500 \mathrm{M}$ hingga 1950 M. Ketiga, periode resurgensi atau kebangkitan kembali, dimulai pada tahun 1950 M hingga sekarang.

Tahap pertama adalah fase yang sangat strategis dalam pengembangan ekonomi Islam. Tahap ini merupakan fase perkembangan teori klasik ekonomi Islam, yang dihasilkan selama kurun waktu 9 abad, meski para tokoh ulama yang muncul di tahap ini tidak menyebutnya sebagai teori ekonomi. Topik-topik yang dibahas pada ilmu ekonomi konvensional modern sesungguhnya telah mendapat pembahasan yang mendalam oleh paratokoh ulama di masa ini, seperti teori tentang uang dan moneter; harga dan pasar; zakat, pajak, dan kebijakan fiskal; pembangunan ekonomi dan peran negara; dan lain-lain.Sejumlah tokoh ulama terkemuka yang menjadi tulang punggung pengembangan teori klasik ekonomi Islam, antara lain adalah Abu Yusuf, Abu Ubaid, al-Ghazali, Ibn Taimiyyah, IbnA al-Qayyim al-Jauziyyah, Ibn Khaldun, AlMaqrizi, dan lain-lain. Karya-karya mereka bahkan masih tetap relevan hingga saat ini.

Selanjutnya, tahap kedua adalah masa dimana perkembangan ekonomi Islam mulai mengalami stagnasi. Hampir tidak ada hal baru yang berkembang pada periode ini. Pada fase ini, yang menjadi representasi utama kekuatan dunia Islam adalah khilafah Turki Usmani, dengan 
kontribusi pentingnya adalah menjadikan wakaf tunai sebagai mesin pertumbuhan ekonomi selama kurang lebih lima abad.Kemudian, kontribusi lain pada tahap ini terkait dengan konsep asuransi takaful atau asuransi syariah. Pada awal abad 19, seorang fuqoha madzhab Hanafi yang bernama Ibn Abidin (1784 - 1836 M), menjadi tokoh ulama pertama yang membahas secara eksplisit definisi, konsep, dan pola transaksi asuransi yang sesuai dengan syariat Islam. Pembahasan tersebut kemudian diperkuat olen Muhammad Abduh melalui fatwanya pada awal abad ke-20. Fase ini juga menjadi saksi tumbuh dan berkembangnya ilmu ekonomi konvensional di daratan Eropa.Sedangkan tahap ketiga adalah tahap kebangkitan kembali ekonomi Islam di pentas dunia. Hingga saat ini, para ekonom Islam masih melakukan proses reformulasi ilmu ekonomi Islam sebagai sebuah disiplin ilmu yang mampu menjawab berbagai tantangan ekonomi dunia.

Selain itu terdapat beberpa pemikir ekonomi islam lainnya di masa klasik, yaitu AlGazali. Fokus pemikiran Al-Gazali tidak hanya menitikberatkan pada satu permasalahan,tetapi juga menyangkut keseluruhan lini dalam kehidupan manusia. Ia melakukan studikeislaman secara luas untuk mempertahankan ajaran agama Islam. Oleh karena itu, kita tidakmenemukan sebuah karya tulisnya yang khusus membahas ekonomi Islam. Perhatiannya dibidang ekonomi itu terkandung dalam berbagai studi fiqihnya, karena ekonomi Islam, padahakikatnya merupakan bagian yang tak terpisahkan dari fiqih Islam. Namun demikian,pemikiran-pemikiran ekonomi alGazali didasarkan pada pendekatan tasawuf, karena masahidupnya, orang-orang kaya, berkuasa, dan sarat prestise sulit menerima pendekatan fiqih danfilosofis dalam mempercayai Yaumal-Hisab. Berkaitan dengan hal ini, al-Gazalimemfokuskan perhatiannya pada perilaku individu yang dibahasnya menurut perspektif al-Qur an, Sunnah, fatwa-fatwa sahabat dan tabi in serta petuah para sufi terkemuka masa sebelumnya.

Perkembangan Ekonomi Islam saat ini tidak bias dipisahkan dari sejarah pemikiranmuslim tentang ekonomi dimasa lalu. Keterlibatan pemikir muslim dalam kehidupan masyarakat yang komplek dan belum adanya pemisahan disiplin keilmuanmenjadikan pemikir muslim melihat masalah masyarakat dalam konteks yang lebih integrative.Pembahaan mengenai perbedaan pendapat ekonom muslim tidak perlu dihindari karena takut akan timulnya perpecahan dalam pengembangan ekonomiislam. 